\title{
Effect of storage and stress conditions on the counts of Bifidobacterium animalis microencapsulated and incorporated in plantain flour
}

\section{Efeito das condições de armazenamento e estresse na contagem de Bifidobacterium animalis microencapsulada e incorporada à farinha de banana-da-terra}

\author{
Eduardo Corpas Iguarán ${ }^{1 *}$ (1), Jessica Triviño-Valencia ${ }^{1}$, Sneyder Rodríguez-Barona² \\ ${ }^{1}$ Universidad Católica de Manizales (UCM), Instituto de Investigación en Microbiología y Biotecnología \\ Agroindustrial (IMBA), Manizales/Caldas - Colombia \\ 2Universidad Nacional de Colombia (UNAL), Departamento de Ingeniería Química, Manizales/Caldas - Colombia
}

*Corresponding Author: Eduardo Corpas Iguarán, Universidad Católica de Manizales (UCM), Instituto de Investigación en Microbiología y Biotecnología Agroindustrial (IMBA), Carrera 23, No. 60-63, apartado 357, Manizales/Caldas - Colombia, e-mail: ecorpas@ucm.edu.co

Cite as: Corpas Iguarán, E., Triviño-Valencia, J., \& Rodríguez-Barona, S. (2020). Effect of storage and stress conditions on the counts of Bifidobacterium animalis microencapsulated and incorporated in plantain flour. Brazilian Journal of Food Technology, 23, e2019252. https://doi.org/10.1590/1981-6723.25219

\begin{abstract}
The probiotic activity in the intestinal microbiota depends on its survival during food storage and its passage through the gastrointestinal tract. This study aimed to evaluate the effect of storage and stress conditions such as temperature, $\mathrm{pH}$ and bile salts on the viability of Bifidobacterium animalis microencapsulated and incorporated in plantain flour. Between days 21 and 28, the failure percentage decreased from $93 \%$ to $27 \%$. The mean counts of B. animalis were statistically different with change of temperature, $\mathrm{pH}$ and bile salt concentration. For the temperature, the counts obtained at $50{ }^{\circ} \mathrm{C}$ and $80{ }^{\circ} \mathrm{C}$ decreased by $60.1 \%$ and $90.2 \%$, respectively. Likewise, at $\mathrm{pH} 2.5$ showed a over $90 \%$ survival reduction during $60 \mathrm{~min}$; whilst at pH 3.5 during $60 \mathrm{~min}$ the survivals were less than $50 \%$. Finally, the counts achieved using $1 \mathrm{~g} / \mathrm{L}$ of bile salts were higher than those obtained at 3 and $5 \mathrm{~g} / \mathrm{L}$. The results indicate the need to evaluate other capsular components to improve the survival of $B$. animalis microencapsulated and incorporated in plantain flour.
\end{abstract}

Keywords: Functional food; Microencapsulation; Plantain flour; Probiotics; Spray dry; Survival.

\section{Resumo}

A atividade probiótica na microbiota intestinal depende de sua sobrevivência, não apenas durante o armazenamento dos alimentos, mas também ao passar pelo trato gastrointestinal. Este estudo visou avaliar o efeito das condições de armazenamento e estresse, como temperatura, $\mathrm{pH}$ e sais biliares, na viabilidade de Bifidobacterium animalis microencapsulado e incorporado à farinha de plátano. Entre os dias 21 e 28 , o percentual de falhas diminuiu de $93 \%$ para $27 \%$. As contagens médias de $B$. animalis foram estatisticamente diferentes ao variar a temperatura, 0 
$\mathrm{pH}$ e a concentração de sais biliares. Em relação à temperatura, as contagens obtidas a $50{ }^{\circ} \mathrm{C}$ e $80{ }^{\circ} \mathrm{C}$ diminuíram $60,1 \%$ e $90,2 \%$, respectivamente. Da mesma forma, $\mathrm{pH} 2,5$ teve redução superior a $90 \%$ a partir dos 60 minutos, enquanto com pH 3,5, durante 60 minutos, as sobrevivências foram inferiores a $50 \%$. Finalmente, as contagens obtidas com $1 \mathrm{~g} / \mathrm{L}$ de sais biliares foram superiores às obtidas com 3 e $5 \mathrm{~g} / \mathrm{L}$. Os resultados indicam a necessidade de avaliar outros componentes capsulares para melhorar a sobrevivência de $B$. animalis microencapsulado e incorporado à farinha de plátano.

Palavras-chave: Alimentos funcionais; Microencapsulação; Farinha de plátano; Probióticos; Secagem por aspersão; Sobrevivência.

\section{Introduction}

Plantain (Musa paradisiaca) is grown in Colombia in an area reserved for cultivation, which corresponds to 590,000 ha (Martínez et al., 2015). This fruit represents $12 \%$ of the total weight of this plant (Gañán et al., 2008). Bearing in mind that plantain is an essential daily diet product and it occupies a relevant place in the national economy, this study aimed at the production of plantain flour, incorporating a microencapsulated probiotic as an alternative to contribute to the improvement of productive efficiency in this value chain.

Probiotics are relevant in the functional food industry and have the capacity to incorporate themselves into the intestinal microbiota, benefiting human health (Champagne et al., 2018; Ranadheera et al., 2018). These lactic acid producers microorganisms are mainly from the Lactobacillus and Bifidobacterium genera (Du Toit et al., 2013; Casarotti \& Penna, 2015; Coghetto et al., 2016). The probiotics survival can be enhanced by microencapsulation, based on the atomization of the microorganism, and its subsequent coating with a protective material, performed in a drying chamber with hot air to remove water in a short time (Fritzen-Freire et al., 2013).

The microencapsulation of $B$. animalis has been studied in dairy products, including goat milk (Ranadheera et al., 2015), ice cream (Silva et al., 2015), fermented milk (Bogsan et al., 2014; Rodrigues et al., 2014), whey (Casarotti \& Penna, 2015; Rodrigues et al., 2011), and yogurt (Akalin et al., 2007). Studies on plantain flour are not known, showing a remarkable and novel aspect of this research. It is noteworthy that a probiotic food must have a count equal to or higher than $10^{6} \mathrm{CFU} / \mathrm{g}$ (Ranadheera et al., 2015). Furthermore, there are evaluative referents of the survival of B. animalis during the storage (Rodrigues et al., 2011), heat stress (Du Toit et al., 2013; Fritzen-Freire et al., 2013), and conditions similar to those that the microorganism faces when going through the gastrointestinal tract (Silva et al., 2015), which are essential to its functionality after preparation and consumption of the food.

We evaluated the effect of storage and stress conditions such as temperature, bile salts, and $\mathrm{pH}$ on the viability of $B$. animalis microencapsulated and incorporated in fortified instant plantain flour. Additionally, the diameter of the microcapsules was analyzed by scanning electron microscopy (SEM).

\section{Material and methods}

\subsection{Drying, extrusion and milling procedure for preparation of plantain flour}

Initially, we selected plantain of the Dominico-Hartón (Musa AAB Simmonds) variety, in stage one of ripening. Then, the plantains were washed with potable water and its disinfection with a commercial agent (Dioxy San at $0.0025 \%$, prepared by mixing $2.5 \mathrm{~mL}$ of the disinfectant and $1000 \mathrm{~mL}$ of potable water). These units were then subjected to blanching, with an internal temperature of $72{ }^{\circ} \mathrm{C}$ for $30 \mathrm{~min}$, and manually separation of the husk adhered to the pulp using a knife. Subsequently, the pulp was chopped, obtaining units in slices of approximately $4 \mathrm{~mm}$, which were later cut into 4 equal parts. The generated pieces were 
dehydrated, using hot air drying under forced convection at $80{ }^{\circ} \mathrm{C}$ for 5 hours, bringing the product to a moisture between 15 and $25 \%$. Later, the dried plantain was milled, with a particle diameter between meshes number 2 and 4 (U.S. STD. Sieve, of 2 and $4.76 \mathrm{~mm}$, respectively). An EX0113 equipment was used for the extrusion process, at $40{ }^{\circ} \mathrm{C}$ and screw speed of $800 \times g$, bringing the product to a moisture of $15-25 \%$ in dry weight. Finally, the material was milled in a domestic mill and the flour was stored under vacuum and at room temperature until its use (Montoya et al., 2016).

\subsection{Preparation of the biomass of $B$. animalis and the encapsulating solution}

The strain of B. animalis ATCC 2557 was isolated in Man, Rogosa and Sharpe (MRS) agar, supplemented with $0.05 \%$ of L-cysteine and incubated at $35 \pm 2{ }^{\circ} \mathrm{C}$ under anaerobic conditions. An isolated colony from B. animalis was inoculated into a flask containing $50 \mathrm{~mL}$ of MRS broth supplemented with $0.05 \%$ of L-cysteine, which remained under constant stirring at $200 \times g$ for 48 hours at $35 \pm 2{ }^{\circ} \mathrm{C}$. Subsequently, the total volume of this preculture was added to a flask containing $500 \mathrm{~mL}$ of MRS broth supplemented with $0.05 \%$ L-cysteine, which was subjected to incubation time for 48 hours at $35 \pm 2{ }^{\circ} \mathrm{C}$ under constant stirring at $200 \times \mathrm{g}$. The biomass was obtained by centrifugation at $5500 \times \mathrm{g}$ for $15 \mathrm{~min}$, followed by discard of the supernatant and subsequent collection of the pellet in sterile $50 \mathrm{~mL}$ Falcon tubes. The obtained biomass was washes three times, subjecting the microorganism in inulin solution, which was centrifuged for $10 \mathrm{~min}$ at $5500 \times g$ (Rodríguez-Barona et al., 2012).

For the encapsulating solution, $250 \mathrm{~g}$ of maltodextrin were added to a bottle containing $1000 \mathrm{~mL}$ of distilled water, which, immediately was placed on a magnetic stirrer for one hour. Later, the bottle with the solution was sterilized at $121{ }^{\circ} \mathrm{C}$ in an autoclave for $15 \mathrm{~min}$. Finally, when the maltodextrin solution was at room temperature, the biomass previously recovered was added, with a proportion of $5 \%$ of biomass in wet weight, with regard to the weight represented by the solution containing the encapsulant compound (Rodríguez-Barona et al., 2012).

\subsection{Microencapsulation of the microbial suspension and incorporation in plantain flour}

The suspension of maltodextrin and biomass of B. animalis was spray dryed in the Buchi-290 equipment (Flawil, Switzerland). Using an atomized vacuum pump, this suspension was transported through a sterile hose to the drying chamber of the equipment. An aspiration of $75 \%$, compressed air of $0.05 \mathrm{Mpa}$, temperature of $80{ }^{\circ} \mathrm{C}$ at the inlet and $40{ }^{\circ} \mathrm{C}$ to $43{ }^{\circ} \mathrm{C}$ at the outlet was supplied. Before entering to the drying equipment, the suspension was constantly stirred at $50 \times \mathrm{g}$, using a magnetic stirrer. The material obtained (18-20 g) was collected in a sterile aluminum packing, which was subsequently subjected to vacuum (Rodríguez-Barona et al., 2012).

The encapsulation efficiency (EE) was calculated according to $\mathrm{EE} \%=(\mathrm{N} / \mathrm{N} 0) \times 100$; where $\mathrm{N}$ is the number of viable cells $\left(\log \mathrm{CFU} \mathrm{g}{ }^{-1}\right)$ released from the microparticles and N0 is the number of free viable cells $\left(\log \mathrm{CFU} \mathrm{g}{ }^{-1}\right)$ in the feed solution before the encapsulation process. EE corresponded to $82 \%$.

For the incorporation into the food matrix, $1 \mathrm{~g}$ of the maltodextrin capsules containing $B$. animalis and $10 \mathrm{~g}$ of the plantain flour were weighed in a $50 \mathrm{~mL}$ Falcon tube, which was subsequently homogenized using a Vortex shaker for $5 \mathrm{~min}$ at $200 \times \mathrm{g}$. This process was performed successively for incorporation of the maltodextrin capsules containing B. animalis in the product plantain flour. The homogeneity of maltodextrin capsules containing $B$. animalis was verified through a Relative Standard Deviation (RSD) of $11 \%$, regarding the mean count of $20.5 \mathrm{E} 9 \mathrm{CFU} / \mathrm{g}$, when analyzing 15 repetitions. Finally, the different treatments of the proposed experiments were arranged. 


\subsection{Analysis of $B$. animalis by counting on plate}

For the analysis of the microorganism in the biomass and maltodextrin suspension, $1 \mathrm{~mL}$ of sample and $9 \mathrm{~mL}$ of buffered peptonated water were mixed, producing the first dilution, from which the serial dilutions necessary to facilitate the counting of this probiotic were made. Similarly, for the estimation in the product, the mixture of $0.1 \mathrm{~g}$ of the sample (B. animalis microencapsulated or plantain flour with this microorganism incorporated) with $1 \mathrm{~mL}$ of peptonated water was considered, generating the suspension from which serial dilutions were subsequently performed. Then, from the dilutions considered, aliquots of $0.1 \mathrm{~mL}$ were inoculated in duplicate on the surface of MRS agar supplemented with $0.05 \% \mathrm{~L}$-cysteine. Finally, incubation was performed at $37^{\circ} \mathrm{C}$ for 72 hours, inside an anaerobic polycarbonate jars with anaerobic indicator sachets (Fritzen-Freire et al., 2012).

\subsection{Experiments performed to establish the effect of storage and stress conditions}

\subsubsection{Viability of $B$. animalis during the storage}

From a production batch obtained, we performed weekly B. animalis analyses, starting on day 1 to day 84 , with 15 repetitions for each sample unit stored at $22{ }^{\circ} \mathrm{C}$ and $80 \%$ RH in Falcon tubes with a capacity of $20 \mathrm{~mL}$. From these counts, the percentage of sample units with counts equal to or higher than 1.0E6, recommended in the resolution 288, was obtained (Colombia, 2008). The reliability percentage has been applied in food to set the time limit until which a particular attribute is fulfilled (Corpas \& Tapasco, 2013).

\subsubsection{Viability of $\boldsymbol{B}$. animalis using different temperatures}

According to Fritzen-Freire et al. (2013), the suspension in buffered peptonated water of the plantain flour with the incorporated microorganism remained 10 min with stirring at $50 \times g$ using different temperatures $\left(22^{\circ} \mathrm{C}, 50^{\circ} \mathrm{C}\right.$, and $\left.80^{\circ} \mathrm{C}\right)$. Then, we performed the analysis to obtain the count of $B$. animalis. These analyzes were performed in sextuplicate and an experimental design of a factor was used. In addition, a control analysis of the $B$. animalis count in the product at room temperature was performed, without the stirring to which underwent treatments aforementioned.

\subsubsection{Viability of B. animalis at different $p H$}

$10 \mathrm{~g}$ of the product with the incorporated microorganism was diluted in $90 \mathrm{~mL}$ buffered peptonated water, with adjustment to three $\mathrm{pH}$ values $(2.5,3.5$, and 6.2$)$, performing analysis of these in sextuplicate, for three contact times $(60,120$, and $180 \mathrm{~min})$. The $\mathrm{pH}$ was adjusted with $37 \% \mathrm{HCL}$ and $0.1 \mathrm{~N} \mathrm{NaOH}$ (Rather et al., 2017). We applied the design of two factors, $\mathrm{pH}$ and contact time, applied to establish differences in the count of $B$. animalis among the treatments. Furthermore, we performed a control count of $B$. animalis in the product, with $\mathrm{pH}$ of 6.2 and immediate analysis, that is, without contact times.

\subsubsection{Viability of B. animalis in the presence of bile salts}

According to Rather et al. (2017), the sample units of plantain flour with the incorporated probiotic were analyzed in sextuplicate, after reconstitution in buffered peptonated water and adjust to three concentrations of bile salts $(1,3$, and $5 \mathrm{~g} / \mathrm{L})$ and three contact times $(60,120$, and $180 \mathrm{~min})$. The design of two factors, bile salts concentration and contact time, was applied to establish their influence on the $B$. animalis count. Likewise, the percentage of decrease of $B$. animalis in the treatments was determined, from a control count without contact of bile salts. 
Effect of storage and stress conditions on the counts of Bifidobacterium animalis microencapsulated and incorporated in plantain flour

Corpas Iguarán, E. et al.

Viability analyzes at different temperatures, $\mathrm{pH}$, and bile salt concentrations were made after product storage time between four and five weeks at $22{ }^{\circ} \mathrm{C}$ and $80 \% \mathrm{RH}$.

\section{Results and discussion}

\subsection{Microscopic characteristics of the maltodextrin capsules}

The microscopic characteristics of both the maltodextrin capsules containing $B$. animalis and the plantain flour were observed by SEM. Figure 1 (left) shows a cluster of microcapsules, with similar diameter and external structure. Furthermore, plantain flour was observed with a bigger size than the microcapsules and with irregular structure that nevertheless, had homogeneity in their general dimensions (Figure 1, right). Immediately after microencapsulation, areas between 61 and $336 \mu \mathrm{m}^{2}$ were obtained, while in the final measurement the areas were between 16 and $39 \mu \mathrm{m}^{2}$. Likewise, after microencapsulation the capsules had semicircular morphology, with slight concavities on the sides; while from the fourth week of storage the capsules had irregular surface and exposed content. Previous studies show capsules with smaller mean diameters (Feng et al., 2018; Ramos et al., 2018), depending on the encapsulation method used.

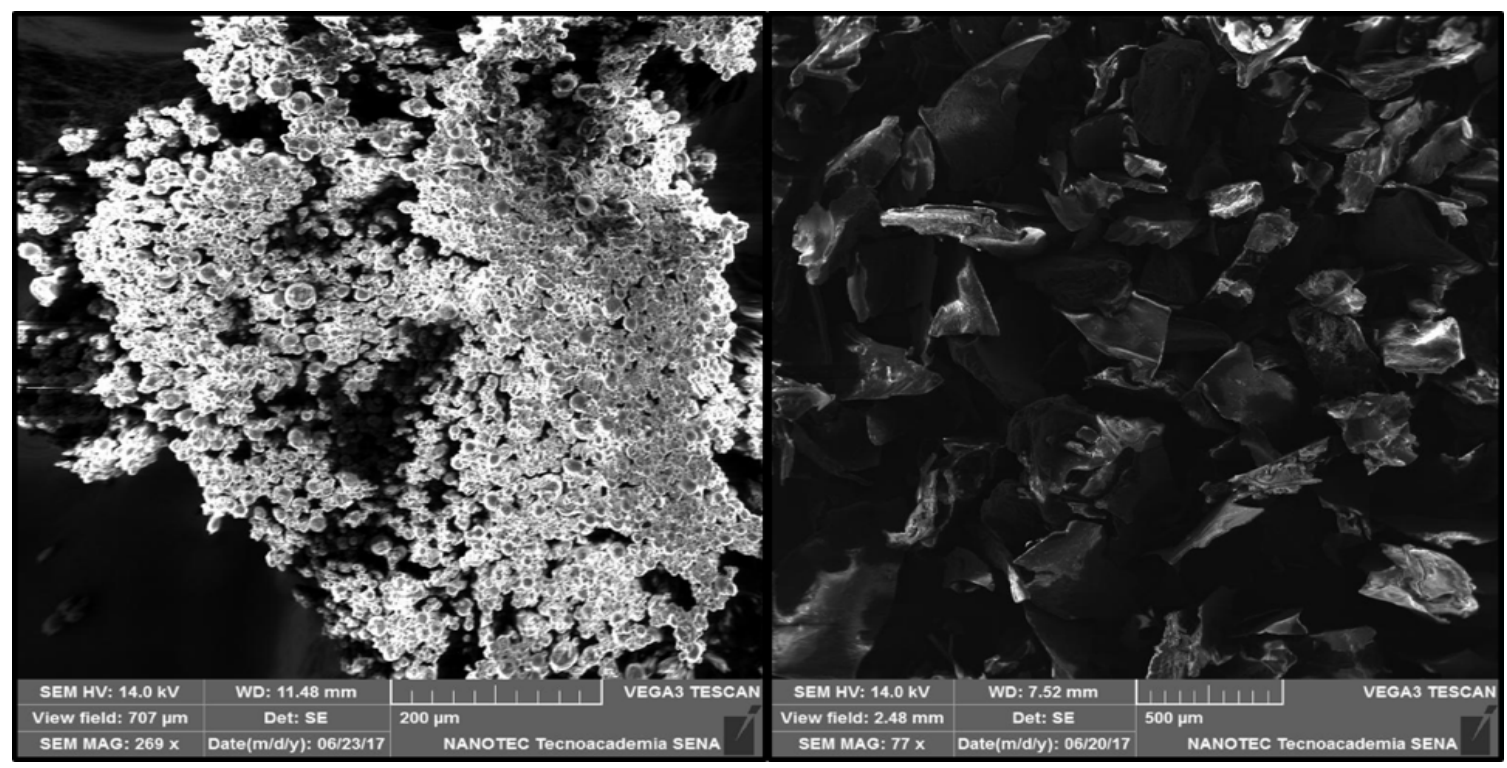

Figure 1. SEM micrograph of B. animalis microencapsulated by spray drying (left) and of the plantain flour (right).

\subsection{Viability during the storage of $B$. animalis microencapsulated and incorporated in plantain flour}

Figure 2 shows the behavior of the $B$. animalis count, transformed to its $\mathrm{Ln}$ for a clearer and esthetic visual appreciation. In general, there was a decrease in the count of this microorganism during the storage. After microencapsulation, there was a mean concentration of $20.5 \mathrm{E} 9 \mathrm{CFU} / \mathrm{g}$, with decrease of 1 logarithmic cycle per week, reaching a mean of 7.4E5 CFU/g on day 21 , where the content of $B$. animalis per gram of the product in $93 \%$ of the sample units analyzed was higher than that required by the respective legislation in Colombia. Contrastingly, on day 28 only $27 \%$ of the samples analyzed complied the aforementioned criteria, with a mean concentration of $8.5 \mathrm{E} 4$. From day 35 , all the samples had counts lower than $1.0 \mathrm{E} 6 \mathrm{CFU} / \mathrm{g}$. 


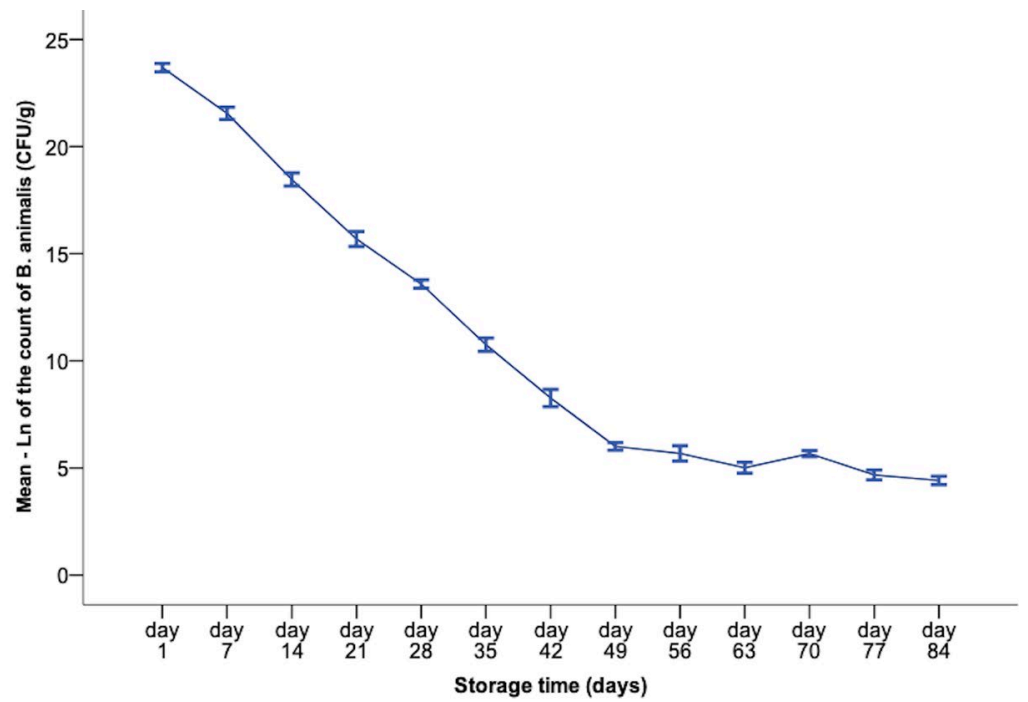

Figure 2. Counting during the storage of B. animalis microencapsulated and incorporated in plantain flour.

Among the main factors that could have affected the viability of $B$. animalis are the encapsulation method and the type of encapsulant material used. In the case of $L$. salivarious microencapsulated by freeze drying with alginate microgels and alginate-gelatin, we observed a decrease in cell viability of $2.4 \log$ and $1.7 \log$, respectively, after 5 weeks under wet condition (Yao et al., 2017). Likewise, at $25{ }^{\circ} \mathrm{C} / 60 \% \mathrm{RH}$ during a storage period of 42 days, the reduction of L. rhamnosus microencapsulated with a material based on alginate, lecithin and starch, was between 1.23 and $2.66 \mathrm{log}$ in different formulations tested (Huq et al., 2017). The microencapsulation by spray drying of $L$. plantarum and $L$. casei based on soybeans at $25^{\circ} \mathrm{C} / 60 \% \mathrm{RH}$ also showed a significant loss of viability after 2 months, which was improved using inulin or oligosaccharides as a wall material (González-Ferrero et al., 2018). These results also show the influence of storage temperature on the reduction of probiotics.

Consistent with the above, it has been established that refrigeration can improve the survival of the probiotics during the storage. The study of the effect of storage temperature on Bifidobacterium $\mathrm{Bb} 12$ inside of microcapsules based on casein showed a higher rate of inactivation at $25^{\circ} \mathrm{C}$, compared to that obtained at $4{ }^{\circ} \mathrm{C}$, where a decrease of about 1 logarithmic cycle was obtained (Heidebach et al., 2010). Furthermore, the storage of $L$. plantarum in refrigeration for 21 days, microencapsulated into a sodium alginate matrix showed survivals close to $9 \log$ (Coghetto et al., 2016). On the other hand, the decrease denoted in this study could be related to the cellular detriment by metabolic reactions such as the oxidation of fatty acids, which produced protein denaturation and phospholipid degradation (Huq et al., 2017). In particular, bacterial storage is related to an increase in the ratio between saturated and unsaturated fatty acids, due to the lipid oxidation, producing free radicals that damage the DNA and cell membranes (Albadran et al., 2015).

\subsection{Effect of temperature on the count of $B$. animalis microencapsulated and incorporated in plantain flour}

Regarding the mean control count, at $22{ }^{\circ} \mathrm{C}$ the mean represented a recovery of $100 \%$. At $55^{\circ} \mathrm{C}$, the mean count meant a reduction of $60.1 \%$. In addition, the mean count of $B$. animalis at $80^{\circ} \mathrm{C}$ indicated a reduction of $90.2 \%$ (Figure 3). The analysis of variance performed later indicated statistical differences between the evaluated treatments $(p=0.00)$. Furthermore, the multiple comparison Tukey's test showed that the mean counts of $B$. animalis were statistically lower when increasing the temperature. Based on the results obtained, the plantain flour with $B$. animalis incorporated inside of microcapsules must be prepared without the supply of temperatures equal to or higher than $50^{\circ} \mathrm{C}$. Our results corroborate with those of another study (Arslan-Tontul \& 
Erbas, 2017), where the exposure for $30 \mathrm{~min}$ of S. boulardii, L. acidophilus and B. bifidum at $80^{\circ} \mathrm{C}$ produced survival rates close to $50 \%$; while at $50{ }^{\circ} \mathrm{C}$, around $90 \%$ of these microorganisms survived.

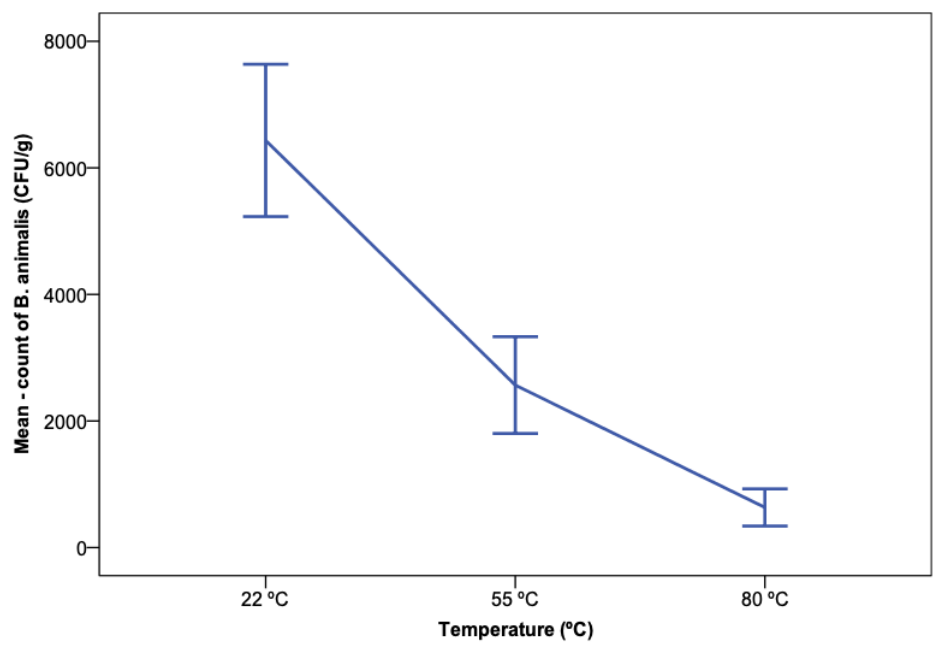

Figure 3. Counting of $B$. animalis microencapsulated and incorporated in plantain flour, subjected to different preparation temperatures.

The protection provided by encapsulation against thermal exposure depends on the temperature and time supplied; however, the composition of the capsular structure also constitutes a differential factor for the protection of the probiotic. As a precedent of this, the thermal supply at $63{ }^{\circ} \mathrm{C}$ for 15 and 30 min showed significantly lower reductions of Lactobacillus salivarious microencapsulated with alginate-gelatin microgels, compared to this microorganism without capsular protection (Yao et al., 2017). In addition, a study performed with $L$. acidophilus showed that the microencapsulated cells by extrusion inside the alginate spheres with double chitosan coat and subjected to $70{ }^{\circ} \mathrm{C}$ for $60 \mathrm{~min}$ had higher survival rate than the cells with simple coat (Jantarathin et al., 2017). Furthermore, L. plantarum and L. casei microencapsulated by freeze drying with alginate double layer coat showed a decrease close to 1.0 and $3.0 \mathrm{log}$, after exposure to $75^{\circ} \mathrm{C}$ for 1 and $10 \mathrm{~min}$, respectively (Rather et al., 2017). These precedents demonstrate the influence of the composition of the capsular structure on the protection of probiotic bacteria.

\subsection{Effect of $\mathrm{pH}$ on the count of B. animalis microencapsulated and incorporated in plantain flour}

Independent of the $\mathrm{pH}$ used, the counts invariably decreased when increasing the contact time. Considering the mean control count, the $B$. animalis count was lower at $\mathrm{pH} 2.5$ compared to those obtained in the other $\mathrm{pH}$ used. Furthermore, we highlight a decrease of $82.8 \%$ after $60 \mathrm{~min}$ of exposure to $\mathrm{pH} 2.5$, compared to a decrease of $21.4 \%$ at $\mathrm{pH} 3.5$ in the same contact time. Another noteworthy aspect is that at $\mathrm{pH} 6.2$ there was a slight decrease in the B. animalis count to a longer time, reaching $21.9 \%$ after $180 \mathrm{~min}$ (Figure 4). The analysis of variance determined the existence of interaction between the evaluated factors $\mathrm{pH}$ and contact time $(p=0.00)$. Finally, the multiple comparison Tukey's test evidenced that the mean values were statistically different when changing $\mathrm{pH}(p=0.00$ among all treatments) and contact time ( $p=0.00$ for $60 \mathrm{~min}$ vs $120 \mathrm{~min} ; p=0.004$ for $120 \mathrm{~min}$ vs $180 \mathrm{~min}$ ). These results indicate the limited efficiency of the capsular structure to protect this microorganism from the diffusion of acidic molecules that cause physical deterioration and disruption of the biological processes in the bacterial cell. 


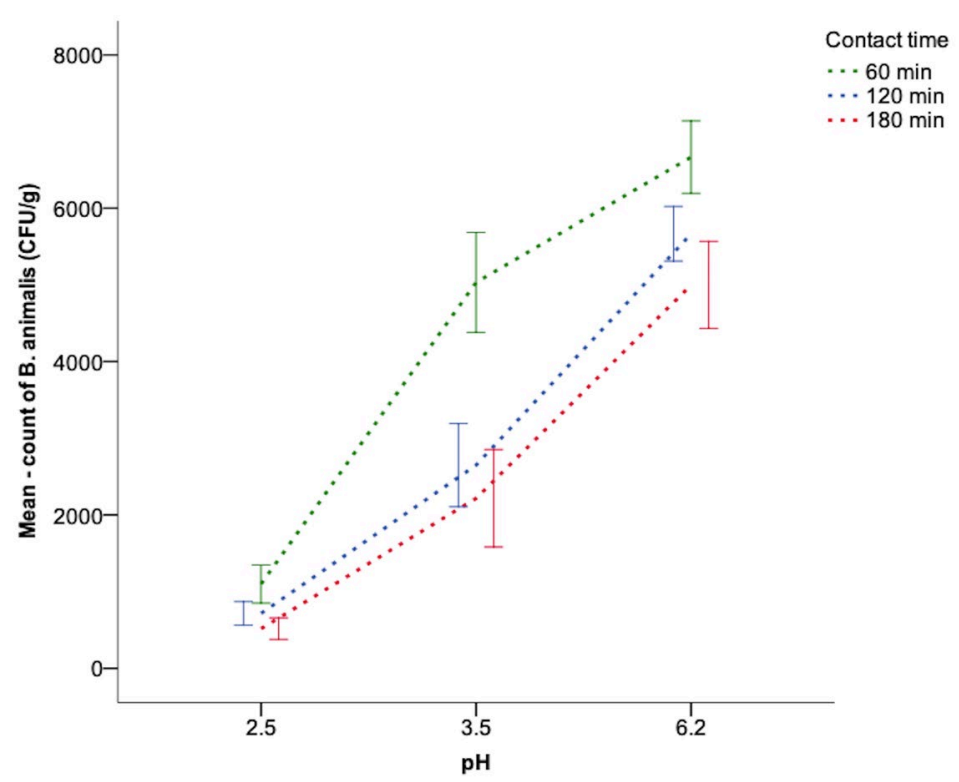

Figure 4. Counting of B. animalis microencapsulated and incorporated in plantain flour, subjected to different $\mathrm{pH}$.

Another aspect susceptible of biological interpretation is that at $\mathrm{pH} 6.2$ the count of $B$. animalis had a reduction directly proportional to the contact time. This allows inferring about the concomitant existence of a degree of deterioration of $B$. animalis at the time of the experiment, as well as a loss of integrity in the maltodextrin capsule, factors that facilitated the subsequent affectation of the microorganism by osmotic stress through the time during the experiment. The argument of a progressive loss in the integrity of B. animalis is supported by the drastic decline occurred in the analysis of the viability during the storage of this microorganism. Compared to the results obtained, other studies show reductions of between 1 and 3 logarithms when microencapsulated strains were in the presence of simulated gastric fluids, during different exposure times (Coghetto et al., 2016; Yao et al., 2017; Huq et al., 2017). The destruction of probiotic microorganisms in the stomach has been related not only to the level of acidity but also to the destruction of the membrane proteins by enzymatic action (Huq et al., 2017), in specific cases such as pepsin and pancreatin, which cause lysis of the bacterial wall (Coghetto et al., 2016). Consequently, a further study could include this factor to establish its effect, concomitant with acidic $\mathrm{pH}$, on the viability of $B$. animalis.

\subsection{Effect of bile salts on the count of $B$. animalis microencapsulated and incorporated in plantain flour}

Based on the mean control count, a significantly higher count of $B$. animalis was obtained when using $1 \mathrm{~g} / \mathrm{L}$ of bile salts, with a maximum decrease of $70.7 \%$ in a contact time of $180 \mathrm{~min}$, compared to the mean counts obtained with 3 and $5 \mathrm{~g} / \mathrm{L}$, concentrations that resulted in reductions of $90.1 \%$ and $94.3 \%$, respectively. Furthermore, in the presence of $1 \mathrm{~g} / \mathrm{L}$ of bile salts, the average reductions were $27.8 \%$ and $35.2 \%$ in the contact times of 60 and $120 \mathrm{~min}$, respectively. Likewise, with all concentrations of bile salts tested against $B$. animalis, the reductions were appreciably higher when there was a contact time of $180 \mathrm{~min}$, compared to those obtained in shorter times (Figure 5). The analysis of variance applied indicated the association of the $B$. animalis count with the bile salts concentration and contact time $(p=0.000)$ without evidence of interaction between these factors $(p=0.969)$. In addition, the Tukey's test showed that the counts in the presence of $1 \mathrm{~g} / \mathrm{L}$ of bile salts were statistically higher than those obtained with higher concentrations $(p=0.000)$ and that the counts obtained with 3 and $5 \mathrm{~g} / \mathrm{L}$ were statistically similar $(p=0.710)$. On the other hand, the counts were significantly lower with a contact time of $180 \mathrm{~min}$, compared to the other times used, whereas there were no statistical differences when comparing the counts at 60 and $120 \min (p=0.309)$. 
The transit of the probiotic through the intestinal tract implies, among other aspects, the need to survive in bile salt concentrations close to $1 \%$ for 60 to $180 \mathrm{~min}$, conditions under which, B. animalis was able to maintain counts similar to those obtained without exposure to bile salts. However, concentrations or times greater than these would probably affect the probiotic capacity of this microorganism.

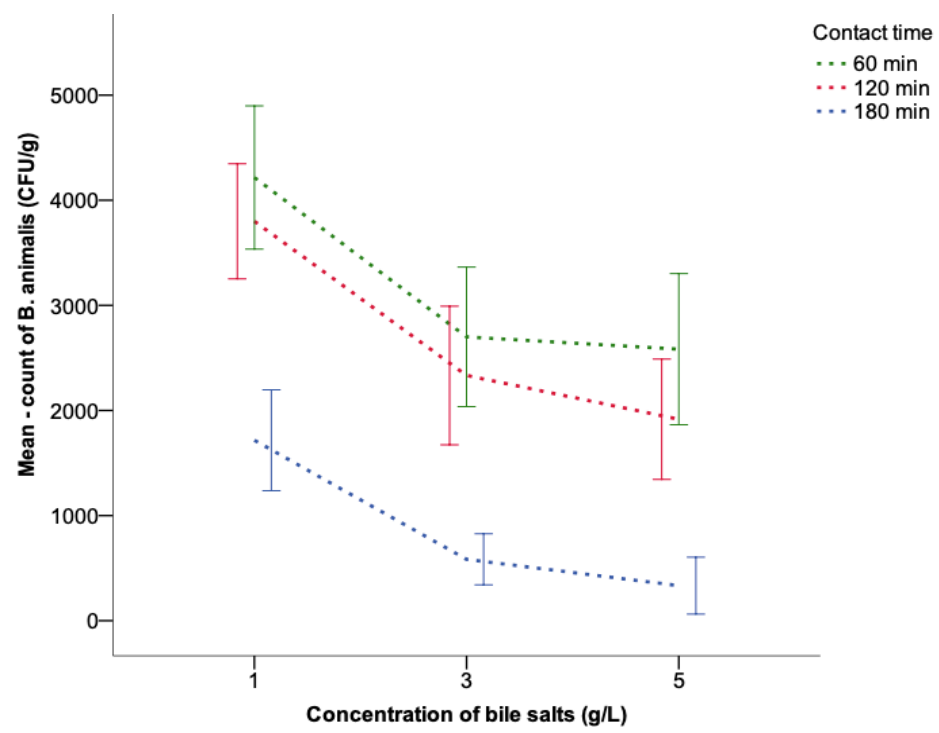

Figure 5. Counting of B. animalis microencapsulated and incorporated in plantain flour, in the presence of bile salts.

It has been indicated that the survival of probiotics under gastrointestinal conditions is related to the impermeability and stability of microcapsules (Coghetto et al., 2016). Furthermore, the hydrophilic material is more easily degraded in the presence of bile salts (Arslan-Tontul \& Erbas, 2017). In the case of maltodextrin, being an amphipathic polymeric component, the prolonged contact time implies a greater possibility of loss of capsular integrity. This explains why the exposure to bile salts, independent of the concentration supplied, promoted a gradual detrimental effect on the capsule, causing drastic decreases of B. animalis when a time of $180 \mathrm{~min}$ was used.

Considering that plantain flour is a food matrix with low $\mathrm{a}_{\mathrm{w}}$, the use of another type of encapsulant could be explored. For example, those based on microgels and microbeads or alternatively, a combination of encapsulant materials of an appropriate nature to prevent deterioration of the capsular integrity, to allow the protection of the probiotic during the storage. In addition, considering that the temperature conditions in microencapsulation can affect the survival capacity during the storage of the microencapsulated microorganism, it would be appropriate to promote the improvement of the viability of $B$. animalis from the effect of controlled stress conditions, of oxidative, thermal, and metabolic nature, prior to the microencapsulation process.

Our findings support some of these considerations. The first aspect is related to the intrinsic survival capacity of the ATCC 2557 strain of $B$. animalis to the factors evaluated; therefore, it would be pertinent to compare their survival capacity against strains of $B$. animalis isolated of the gastrointestinal tract, as well as establish the respective metagenomic understanding. Another aspect is the importance of exploring the integration of prebiotic formulations that include oligosaccharides, to improve the viability of the probiotic in the product (Langa et al., 2019). Likewise, although the in vitro evaluation of the survival capacity against the variables used allows inferring about the probiotic potential of the microorganism, it is necessary to explore simulation models that facilitate an approach to the conditions of the gastrointestinal tract (Silva et al., 2015), and contemplate the influence of other variables such as the content and type of nutrients, the osmotic pressure, and the presence and activity of other microorganisms. 
Regarding the consumer perception, some studies have demonstrated that sensory characteristics of the probiotic product are related to willingness, consumption motivations, and buyers' profile (Cruz et al., 2013; Pinto et al., 2018). This implies the need of performing sensory test to the plantain flour with the probiotic incorporated, in order to identify the market opportunities, consider changes in the formulation, and include the characteristics associated with the product in marketing strategies.

\section{Conclusions}

B. animalis microencapsulated and incorporated in plantain flour, survived on this product for 3 weeks at the recommended concentration to its probiotic activity. Furthermore, at $\mathrm{pH}$ lower than 3.5 and concentrations of bile salts greater than $1 \mathrm{~g} / \mathrm{L}$ the counts of $B$. animalis had significant reduction after 120 minutes of exposure, which is related to the loss of capsular integrity. Due to the susceptibility of the encapsulated microorganism, we do not recommend heating the product during its preparation.

\section{Acknowledgements}

The authors would like to thank to the Servicio Nacional de Aprendizaje SENA - Regional Caldas, for the assistance in the observations of the microencapsulation of $B$. animalis through the SEM.

\section{References}

Akalin, A. S., Tokuşoğlu, Ö., Gönç, S., \& Aycan, Ş. (2007). Occurrence of conjugated linoleic acid in probiotic yoghurts supplemented with fructooligosaccharide. International Dairy Journal, 17(9), 1089-1095. http://dx.doi.org/10.1016/j.idairyj.2007.02.005

Albadran, H. A., Chatzifragkou, A., Khutoryanskiy, V. V., \& Charalampopoulos, D. (2015). Stability of probiotic Lactobacillus plantarum in dry microcapsules under accelerated storage conditions. Food Research International, 74, 208-216. PMid:28411985. http://dx.doi.org/10.1016/j.foodres.2015.05.016

Arslan-Tontul, S., \& Erbas, M. (2017). Single and double layered microencapsulation of probiotics by spray drying and spray chilling. Lebensmittel-Wissenschaft + Technologie, 81, 160-169. http://dx.doi.org/10.1016/j.Iwt.2017.03.060

Bogsan, C. S., Ferreira, L., Maldonado, M. C., Perdigon, G., Almeida, S. R., \& Oliveira, M. N. (2014). Fermented or unfermented milk using Bifidobacterium animalis subsp. lactis HN019: Technological approach determines the probiotic modulation of mucosal cellular immunity. Food Research International, 64, 283-288. PMid:30011652.

http://dx.doi.org/10.1016/j.foodres.2014.05.036

Casarotti, S. N., \& Penna, A. L. B. (2015). Acidification profile, probiotic in vitro gastrointestinal tolerance and viability in fermented milk with fruit flours. International Dairy Journal, 41, 1-6. http://dx.doi.org/10.1016/j.idairyj.2014.08.021

Champagne, C. P., Gomes, A., \& Daga, M. (2018). Strategies to improve the functionality of probiotics in supplements and foods. Current Opinion in Food Science, 22, 160-166. http://dx.doi.org/10.1016/j.cofs.2018.04.008

Coghetto, C. C., Brinques, G. B., Siqueira, N. M., Pletsch, J., Soares, R. M. D., \& Ayub, M. A. Z. (2016). Electrospraying microencapsulation of Lactobacillus plantarum enhances cell viability under refrigeration storage and simulated gastric and intestinal fluids. Journal of Functional Foods, 24, 316-326. http://dx.doi.org/10.1016/j.jff.2016.03.036

Colombia. Ministerio de la Protección Social. (2008, enero 31). Resolución $n^{\circ} 288$. Reglamento técnico sobre los requisitos de rotulado o etiquetado nutricional que deben cumplir los alimentos envasados para consumo humano. Retrieved in 2019, July 4 , from https://www.invima.gov.co/images/stories/resoluciones/resolucion_0288de2008_rotuladoyetiquetado.pdf

Corpas, E. J., \& Tapasco, O. A. (2013). Comportamiento de mohos en arepa blanca asada en relación al tiempo de almacenamiento en refrigeración. Alimentos Hoy, 22, 23-39. Retrieved in 2019, July 4, from http://www.alimentoshoy.acta.org.co/index.php/hoy/article/view/153/147

Cruz, A. G., Cadena, R. S., Castro, W. F., Esmerino, E. A., Rodrigues, J. B., Gaze, L., Faria, J. A., Freitas, M. Q., Deliza, R., \& Bolini, H. M. (2013). Consumer perception of probiotic yogurt: Performance of check all that apply (CATA), projective mapping, sorting and intensity scale. Food Research International, 54(1), 601-610. http://dx.doi.org/10.1016/j.foodres.2013.07.056

Du Toit, E., Vesterlund, S., Gueimonde, M., \& Salminen, S. (2013). Assessment of the effect of stress-tolerance acquisition on some basic characteristics of specific probiotics. International Journal of Food Microbiology, 165(1), 51-56. PMid:23688551. http://dx.doi.org/10.1016/j.jifoodmicro.2013.04.022

Feng, K., Zhai, M., Zhang, Y., Linhardt, R. J., Zong, M., Li, L., \& Wu, H. (2018). Improved viability and thermal stability of the probiotics encapsulated in a novel electrospun fiber mat. Journal of Agricultural and Food Chemistry, 66(41), 10890-10897. PMid:30260640. http://dx.doi.org/10.1021/acs.jafc.8b02644

Fritzen-Freire, C. B., Prudêncio, E. S., Amboni, R. D. M. C., Pinto, S. S., Negrão-Murakami, A. N., \& Murakami, F. S. (2012). Microencapsulation of bifidobacteria by spray drying in the presence of prebiotics. Food Research International, 45(1), $306-312$. http://dx.doi.org/10.1016/j.foodres.2011.09.020 
Fritzen-Freire, C. B., Prudêncio, E. S., Pinto, S. S., Muñoz, I. B., \& Amboni, R. D. (2013). Effect of microencapsulation on survival of Bifidobacterium BB-12 exposed to simulated gastrointestinal conditions and heat treatments. LebensmittelWissenschaft + Technologie, 50(1), 39-44. http://dx.doi.org/10.1016/j.Iwt.2012.07.037

Gañán, P., Zuluaga, R., Restrepo, A., Labidi, J., \& Mondragon, I. (2008). Plantain fibre bundles isolated from Colombian agroindustrial residues. Bioresource Technology, 99(3), 486-491. PMid:17350832. http://dx.doi.org/10.1016/j.biortech.2007.01.012 González-Ferrero, C., Irache, J. M., \& González-Navarro, C. J. (2018). Soybean protein-based microparticles for oral delivery of probiotics with improved stability during storage and gut resistance. Food Chemistry, 239, 879-888. PMid:28873648. http://dx.doi.org/10.1016/j.foodchem.2017.07.022

Heidebach, T., Först, P., \& Kulozik, U. (2010). Influence of casein-based microencapsulation on freeze-drying and storage of probiotic cells. Journal of Food Engineering, 98(3), 309-316. http://dx.doi.org/10.1016/j.jfoodeng.2010.01.003

Huq, T., Fraschini, C., Khan, A., Riedl, B., Bouchard, J., \& Lacroix, M. (2017). Alginate based nanocomposite for microencapsulation of probiotic: Effect of cellulose nanocrystal (CNC) and lecithin. Carbohydrate Polymers, 168, 61-69. PMid:28457464. http://dx.doi.org/10.1016/j.carbpol.2017.03.032

Jantarathin, S., Borompichaichartkul, C., \& Sanguandeekul, R. (2017). Microencapsulation of probiotic and prebiotic in alginatechitosan capsules and its effect on viability under heat process in shrimp feeding. Materials Today: Proceedings, 4(5), 61666172. http://dx.doi.org/10.1016/j.matpr.2017.06.111

Langa, S., van den Bulck, E., Peiroten, A., Gaya, P., Schols, H. A., \& Arques, J. L. (2019). Application of lactobacilli and prebiotic oligosaccharides for the development of a synbiotic semi-hard cheese. Lebensmittel-Wissenschaft + Technologie, 114, 1-6. http://dx.doi.org/10.1016/j.Iwt.2019.108361

Martínez, C., Cayón, G., \& Ligarreto, G. (2015). Physiological attributes of banana and plantain cultivars of the Colombian Musaceae Collection. Agronomia Colombiana, 33(1), 29-35. http://dx.doi.org/10.15446/agron.colomb.v33n1.45935

Montoya, J., Rodríguez-Barona, S., \& Giraldo, G. (2016). Características fisicoquímicas de la harina de plátano (Musa Paradisiaca) Dominico Harton y harina de trigo comercial con tendencias funcionales. Vitae, 23(Suppl. 1), S396-S399. Retrieved in 2019, July 4, from https://aprendeenlinea.udea.edu.co/revistas/index.php/vitae/article/view/26175/20779691 Pinto, L. P., Silva, H. L., Shigeno, P. K., Maçaira, P. M., Cyrino, F. L., Cruz, A. G., Esmerino, E. A., \& Freitas, M. Q. (2018). Understanding perceptions and beliefs about different types of fermented milks through the application of projective techniques: A case study using Haire's shopping list and free word association. Journal of Sensory Studies, 33(3), e12326. http://dx.doi.org/10.1111/joss.12326

Ramos, P. E., Silva, P., Alario, M. M., Pastrana, L. M., Teixeira, J. A., Cerqueira, M. A., \& Vicente, A. A. (2018). Effect of alginate molecular weight and $\mathrm{M} / \mathrm{G}$ ratio in beads properties foreseeing the protection of probiotics. Food Hydrocolloids, 77, 816. http://dx.doi.org/10.1016/j.foodhyd.2017.08.031

Ranadheera, C. S., Naumovski, N., \& Ajlouni, S. (2018). Non-bovine milk products as emerging probiotic carriers: Recent developments and innovations. Current Opinion in Food Science, 22, 109-114. http://dx.doi.org/10.1016/j.cofs.2018.02.010 Ranadheera, C., Evans, C., Adams, M., \& Baines, S. (2015). Microencapsulation of Lactobacillus acidophilus LA-5, Bifidobacterium animalis subsp. lactis BB-12 and Propionibacterium jensenii 702 by spray drying in goat's milk. Small Ruminant Research, 123(1), 155-159. http://dx.doi.org/10.1016/j.smallrumres.2014.10.012

Rather, S. A., Akhter, R., Masoodi, F. A., Gani, A., \& Wani, S. M. (2017). Effect of double alginate microencapsulation on in vitro digestibility and thermal tolerance of Lactobacillus plantarum NCDC201 and L. casei NCDC297. Lebensmittel-Wissenschaft + Technologie, 83, 50-58. http://dx.doi.org/10.1016/j.lwt.2017.04.036

Rodrigues, A. C., Béal, C., da Silva, R. C., \& Nogueira, M. (2014). Survival of three Bifidobacterium animalis subsp. lactis strains is related to trans-vaccenic and $\alpha$-linolenic acids contents in organic fermented milks. Lebensmittel-Wissenschaft + Technologie, 56(2), 290-295. http://dx.doi.org/10.1016/j.Iwt.2013.11.036

Rodrigues, D., Sousa, S., Rocha-Santos, T., Silva, J. P., Sousa Lobo, J. M., Costa, P., Amaral, M. H., Pintado, M. M., Gomes, A. M., Malcata, F. X., \& Freitas, A. C. (2011). Influence of I-cysteine, oxygen and relative humidity upon survival throughout storage of probiotic bacteria in whey protein-based microcapsules. International Dairy Journal, 21(11), 869-876. http://dx.doi.org/10.1016/j.idairyj.2011.05.005

Rodríguez-Barona, S., Orrego, C. E., \& Montes, L. M. (2012). Microencapsulación de probióticos mediante secado por aspersión en presencia de prebióticos. Vitae, 19(Suppl.1), S186-S188. Retrieved in 2019, July 4, from https://www.redalyc.org/pdf/1698/169823914053.pdf

Silva, P. D. L., Bezerra, M. F., Santos, K. M. O., \& Correia, R. T. P. (2015). Potentially probiotic ice cream from goat's milk: Characterization and cell viability during processing, storage and simulated gastrointestinal conditions. LebensmittelWissenschaft + Technologie, 62(1), 452-457. http://dx.doi.org/10.1016/j.Iwt.2014.02.055

Yao, M., Wu, J., Li, B., Xiao, H., McClements, D. J., \& Li, L. (2017). Microencapsulation of Lactobacillus salivarious Li01 for enhanced storage viability and targeted delivery to gut microbiota. Food Hydrocolloids, 72, 228-236.

http://dx.doi.org/10.1016/j.foodhyd.2017.05.033 